\title{
HELLP syndrome, A real general disease that threatens the maternal morbidity and mortality at the EHU in Oran
}

\author{
Setti Aouicha Zelmat*, N Belhachemie, D Bouabida K \\ Kerbouia, E Boucherit and F Mazour
}

Resuscitation, Specialized Hospital, oran, Algeria

Received: 08 April, 2020
Accepted: 30 April, 2020
Published: 01 May, 2020

*Corresponding author: Setti Aouicha Zelmat, Resuscitation, SpecializedHospital, oran, Algeria, E-mail: Settiaouichazelmat@yahoo.fr

https://www.peertechz.com

Check for updates

\section{Introduction}

Hellp Syndrome (hemolysis, elevatedliver enzymes, lowplatelet count) is an obstetric emergency. It is a form of severity of preeclampsia, itsdiagnosisisdifficultbecause the biologicalpictureisoftenincomplete and rough [1-6]. Several classifications have emerged, the best knownisthat of MISSISSIPI. [7-10], defined by:

Class 1: la plus grave, avec :

Platelet count 1 à $\leq 50,000 / \mathrm{ml}$. ASAT orALAT $\geq 70 \mathrm{IU} / \mathrm{L}$. $. \mathrm{LDH} \geq 600 \mathrm{IU} / \mathrm{L}$

Class 2: Platelet count $500,000 / \mathrm{ml}-100,000 / \mathrm{ml}$. ASAT or ALAT $\geq 70 \mathrm{IU} / \mathrm{L}$. LDH $\geq 600 \mathrm{IU} / \mathrm{L}$.

Class 3: Platelet count $100,000 / \mathrm{ml} \_150000 / \mathrm{ml}$. ASAT or ALAT $\geq 70$ I. $\mathrm{LDH} \geq 600 \mathrm{IU} / \mathrm{L}$.

It is a syndrome thatisoftenvery progressive, sometimeshyperacute in the form of a multi-visceralfailure syndrome. This pathologyisendowedwith a heavymaternofetalmorbidity and mortality. Maternalmorbidityis all the more severe as the diagnosisis made late [11]. HS isassociatedwith $40 \%$ of severematernal complications [12], compared to $10 \%$ in isolatedseverepre-eclampsia. Incomplete or partial forms have a more favorable maternalprognosisthancompleteformscorrelatedwith the severity of preeclampsia.

Regardless of biologicalcriteria [13]. HS complications are related to systemicfailurecaused by disseminated microangiopathy. Multi-visceralgravidarfailureis an evolution of the diseasebeyond HS and not an intrinsic complication of HS [14].

The main objective of ouris to determine the incidence of complications related to the HELLP syndrome at the gynecologicalobstetricsdepartment of the UniversityHospital Oran.

\section{Patients and methods}

\section{Type of study}

Weconducted a cross-sectionalstudy over 4 yearsfromJanuary 1st, 2015 to December 31st, 2019, in the Gynecology and ObstetricsDepartment of the Oran EHU, in patients with HS.

\section{Study population}

The studyconcerns all patients withpre- or post-partum HS whowereadmitted to the Gynecology and ObstetricsDepartment of Oran EHU.

\section{Criteria for non-inclusion are:}

- Class III HS according to the MISSISSIPI classification.

- Thrombocytopenia due to another cause (congenital, thrombocytopenic purpura, uremichemolytic syndrome, hepaticsteatosis).

- An elevation of ASAT and LDH due to another cause.

We first describe the clinicalcharacteristics of the population, including all the patients included in the "2013 to 2016" study, wethenstudy 


\section{Factorsstudied}

maternal and fetal complications related to HS: complications consideredwerematernaldeaths, neurological complications (eclampsia, retro placentalhematoma, sub-capsularhematoma of the peroperative and fetal liver (in utero death, spontaneous or iatrogenicprematurity and intrauterinegrowth retardation)

\section{Sample size}

Takingintoaccount the prevalence of PE reported in the literature, wecalculatedthatat least 165 cases of pregnantwomenshouldbeincluded.

\section{Practicalorganization}

The patient with HS isexaminedrapidly, and her file isseen by the resuscitator, whoassesses the degree of urgency and determines, in collaboration with the obstetrician, the orientation, either in intensive care unit or in GHR unit, or in the operating room or at the delivery block.

\section{The unit of high-riskpregnancies}

The major role of the resuscitatorwho must initiate emergency therapyis:

- The stabilization of the lesionwithantihypertensivetherapywith the electric syringe and orallywith a monitoring of the vital parameters.

- Corticotherapy for pulmonarymaturity and targetedplatelet.

- Transfusion of platelet pellet in HS type 1 (thrombocytopenia $\leq 50000$ )

- Monitoring of the clinical and biologicalevolution of HS thatisunpredictable

- The search for complications: .eclampsia ,oedemaaugue of the lung ,

placental retro hematoma, renalfailure ,hematomaundercapsularliver.

This involves the collaboration of the departments of biology, biochemistry of hemobiology, radiology, hematology and transfusion center.

The passage to the operating room: The treatment of HS isrepresentedprimarily by the termination of pregnancy but thisdecisionmaybeshifted in certain cases, after a multidisciplinarydecision of the resuscitator, the obstetrician and the pediatrician. The important role of the resuscitatoranesthesiologist in the operating room, whichoftenrepresents more than $50 \%$ of the decision-to-birth time, must betakenintoaccount by the choice of the type of anesthesiaaccording to the context, and the management of the per and post complications. procedure.

Criteria for transfer to intensive care: It isrecommended to anticipate and organize the continuous surveillance of patients presenting or likely to have one or more organfailures, related to a severeobstetricpathology, or with a maternalpathologycomplicated by pregnancy, and to orient the patient to a resuscitation unit in the event of persistingorganfailurerequiring replacement, multivisceralfailure or life-threatening conditions according to the agreement establishedbetweeneach unit of obstetrics and an adult intensive care unit, especially if the establishment where the maternitywardislocated has it.

Statisticalanalysis: The descriptive analysis of the variables isdone by calculatingfrequencies, characteristics of central tendency or dispersion: the mean (m), the median (me), the variance $(\sigma 2)$, the standard deviation $(\sigma)$ as well as the determination of the confidence intervals (95\% CI) around the mean, and the median (me) for the risk $\alpha=0.05$ for the quantitative variables.

The determination of frequencies and confidence intervals for qualitative variables.

The confidence intervalaround the meanisshown by the Standard Deviationaround the mean (mean $\pm \mathrm{SD}$ ).

\section{Result}

\section{Population of the study population}

During the studyperiod, wecollected 165 cases of HS out of a total of 20,283 deliveries. The estimated incidence of this syndrome is $0.8 \%$, or 1 case for 116 pregnancies. Wefound 167 pre-eclamptic patients admittedduring the sameperiod, the incidence of $\mathrm{HS}$ in preeclamptic patients collectedduring the sameperiodis $14.13 \%$.

Of these 165 patients, 121 (73.3\%) weretransferredfromanotherperipheralhealthfacility. And 44 patients (26.7\%) werereferred to the specialized consultation service of the Oran EHU,

Our patients are mainlymultiparas; the frequency of the multiparityis $45 \%$, the nulliparousis $28.5 \%$ and the primiparityis $26.5 \%$. The averageparity in our patients is $2 \pm$ 1 childrenwithextremesrangingfrom 0 to 9 with a median of 1.The averageage of our patients is $32 \pm 6.33$. Pregnancywas not regularlyfollowedin 97 patients, or $59 \%$. HS wasdiagnosedat an averageterm of 33 weeks of amenorrhea.

\section{Incidences of maternal complications}

In ourstudy, 105 patients had complications, $63.6 \%$ of whichincludedmaternaldeaths $(n=10)$,

Wenoted 38 cases of eclampsia: (23, 03\%), 20 cases of HRP (12.12\%), 17 patients complicated of CIVD (10.3\%), and 10 patients complicatedwith PAO: HSCF wasfoundin 11 patients $(6.06 \%)$, and retinaldetachmentwasfoundin 2 patients $(1.21 \%)$ and encephalopathyin 3 patients (1.81\%). The diagnosis of acute pulmonaryedemaisbased on clinical and radiological data. Abdominal ultrasoundwasperformedsystematically, in view of the persistence of abdominal pain in search of HSCF. 
CIVD wasdefined by the combination of thrombocytopenialessthan 100,000 platelets / $\mathrm{mm}-3$, fibrinogen $<3 \mathrm{~g} /$ Let, the presence of fibrindegradationproducts or D-dimer $>3 \mu \mathrm{g} / \mathrm{mL}$.

It isnotedthat acute renalfailurediagnosedwith RIFLE criteriawas the mostfrequent complication foundin 62 patients (37.75\%), whichwasestablishedafter an averagedelay of 4.5 after admission of HS. , Diuresiswasretainedin 9 patients while 53 parturientswasoliguricthree patients required extrarenal treatmentwith an average of $6 \pm 2.2$ sessions per patient, 1 has evolved to chronicrenalfailure,

\section{Impact of fetal complications}

The rates of prematurity (ofteniatrogenic), IUGR and MFIU, were $52,7 \%, 87.4 \%$ and $26 \%$ respectively and noted 23 newbornswhodiedatbirth,

\section{Discussion}

Our results are consistent in part withthose of the Leboterfseries [15], in 2003, Kirkpatrick [16], in 2008 and Roopa [17], in 2010, with an incidence of HS in relation to the number of pregnanciesrangingfrom 0.2 to $1 \%$ of pregnancies.

In 2012, in a retrospectiveMoroccanstudyin 2008, Mamouni [18], out of 61 cases found an incidence of $0.27 \%$, of which $67 \%$ weretransfersfromperipheralmaternityhospitals.

In ourstudy, 105 patients had complications, 63.6\% whichissimilar to the Mamouni study117 with $74 \%$ of the complications, and the study of Hani bilal45 with $52 \%$.But ourresults are superior to the study of Sibaï [19], in 1993 and Beucher [13], in 2008 whofoundthat HS isassociatedwith $40 \%$ of maternal complications.

The authors $[13,20]$, findthat the complications are all the more important that the diagnosisis made late. This shows that the discovery of HS islate in ourcontext. So weattribute the complicationsinourstudytoalateconsultation, anon-monitoring pregnancy or adeceptiveclinicalpicturethatiscertainlyat the origin of a lateevacuation

In ourseries, acute renalfailurewas the mostcommon complication with $39.4 \%$. This is consistent with a Tunisianstudydonein 2000 by Ben letaifa [21], whofoundthat acute renalfailurewas. morefrequentlyfoundin $1 / 3$

cases. This isexplained by the authors, by the constant association, with the vascular-renaldisease, of a dehydrationfavored by the digestive disorders.

\section{Conclusion}

The incidence of HS in our institution is high by around $0.8 \%$, due to a high frequency of peripheraltransfers, whichis a clear invitation to action to improve screening, surveillance and treatmentat the periphery

HS is a seriousdisease for the mothersinceitcanpresentitself in the form of a multi-visceralfailure, and fatal for the fetus the precocity of the treatmentis the onlyguarantee of a betterprognosis.

\section{References}

1. Medhioub KF, ChaariA, Turki O, Rgaieg K, Baccouch N , et al. (2016) Actualités sur le syndrome Hellp (Hemolysis, ElevatedLiver enzymes and LowPlatelets); revmed interne 37: 406-411. Link: https://bit.ly/3aln7re

2. Weinstein L (1982) Syndrome of hemolysis, elevated liver enzymes, and low platelet count: a severe consequence of hypertension in pregnancy. ;Am J Obstet Gynecol 142: 159-167. Link: https://bit.ly/2VKeM1U

3. Pourrat O, Pierre F, Magnin G (2009) Le syndrome HELLP: les dix commandements. Revue de médecine interne 30: 58-64. Link: https://bit.ly/2W6AU5C

4. Bacq Y (1997) Acute fatty liver in pregnancy. Gastroenterol Clin Biol 21: 109115. Link: https://bit.ly/2yUWNga

5. Sibai BM, Ramadan MK, Usta I, Salama M, Mercer BM, et al. (1993) Maternalmorbidity and mortalityin 442 pregnancieswithhemolysiselevatedliver enzymes and lowplatelets (HELLP syndrome). Am J Obstet Gynecol 169 1000-1006. Link: https://bit.ly/2KITQIB

6. Beaufils M (2002) Hypertension artérielle gravidique. Rev Med Interne 23: 927 938

7. Carles G (2009) Hellp syndrome/Formes cliniques et étiologies alternatives Obstétrique 2009. URL: https://bit.ly/3cVVk8c

8. Martin JN, Rose $\mathrm{CH}$, Briery $\mathrm{CM}$ (2006) Understanding and managing HELLP syndrome: the integralrole of aggressive glucocorticoids for mother and child. Am J Obstet Gynecol 195: 914-934. Link: https://bit.ly/3aH32la

9. Martin JN, Blake PG, Perry KG, Mc Ccaul JF, Hess LW, et al. (1991)The naturalhistory of HELLP syndrome: patterns of disease progression and regression. Am J Obstet Gynecol 164: 1500-1509. Link: https://bit.ly/35e8jzs

10. Roberts JM, Gammill HS (2005) Preeclampsia: recent insights. Hypertension 46: 1243-1249. Link: https://bit.ly/2y1nFvf

11. Barton JR, Sibai BM (1991) Care of the pregnancycomplicated by HELLP syndrome. Obstet Gynecol Clin North Am 18: 165-179, Link: https://bit.ly/2xhSDP6

12. Haddad B, Barton JR, Livingston JC, Chahine R, Sibai BM (2000) Riskfactors for adverse maternaloutcomesamongwomenwith HELLP (hemolysis, elevatedliver enzymes, and lowplatelet count) syndrome. Am J Obstet Gynecol 183: 444-448. Link: https://bit.ly/2VKdzb0

13. Beucher G,Simonet T, Dreyfus M (2008) Prise en charge du HELLP syndrome. Gynecol Obstet Fertil 36: 1175-1190. Link: https://bit.ly/2YgmqTJ

14. Edouard D (2000) Le syndrome Hellp,Vers une définition de la durée du traitement conservateur. Ann Fr Anesth Réanim 19 : 710-127. Link: https://bit.ly/3f1yDRV

15. LeBoterff C, Masson D (2003) Decouverte d'un Hellp syndrome asymptomatique chez une jeune femme drepanocytaireheterozygote $A / S$ Revue Française des laboratoires 57-59. Link: https://bit.ly/2SkP7uy

16. Kirkpatrick CA (2010) The help syndrome; Acta Clinica Belgica 65: 91-97. Link: https://bit.ly/3bOlusm

17. Roopa S, Hegde HV, BhatPai R, Yaliwal VG, RaghavendraRao P (2010) A case of atypical HELLP (hemolysis, elevatedliver enzymes and lowplatelet count) syndrome presenting as bleedingfrom the epiduralpuncture site during; labour. Current Anaesthesia Critical Care 21: 153-155. Link: https://bit.ly/3alkLbS

18. Mamouni N, Bougern H, Derkaoui A, Bendahou K, Fakir S, et al. (2012) Le HELLP syndrome: à propos de 61 cas et revue de la littérature. Pan Afr Med $\mathrm{J}$ 11: 30. Link: https://bit.ly/3d14sZ4

Citation: Zelmat SA, Belhachemie N, Kerbouia DBK, Boucherit E, Mazour F (2020) HELLP syndrome, A real general disease that threatens the maternal morbidity and mortality at the EHU in Oran. J Cardiovasc Med Cardiol 7(2): 094-097. DOI: https://dx.doi.org/10.17352/2455-2976.000120 
19. Sibai BM, Ramadan MK (1993) Acuterenalfailure in pregnanciescomplicated by hemolysis, elevatedliver enzymes and lowplatelets. Am J Obstet Gynecol 168:1682-1690. Link: https://bit.ly/2KGgxHh

20. Robert S, Egerman MD, Baha M, Sibai MD (1999) Hellp syndrome; Clin Obst et Gynecol 42: 381-389. Link: https://bit.ly/2YeQKOD
21. BenLetaifa D, Ben Hamada S, Salem N, Ben Jazia K, Slama A, et al. (2000) Morbidité et mortalité materno-foetales associées auHellp syndrome: Ann $\mathrm{Fr}$ AnesthRéanim 19 : 712-718. Link: https://bit.ly/3f3HWAU

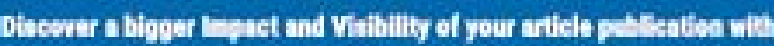
Peertechz Publlieations

\section{HighWghts}

- Sipnatsryputanet af ONoD

- Sonatsy Putisher of DCFA (Ban Francisos Desbates an Research Assessment)

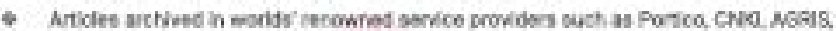

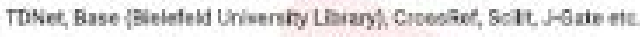

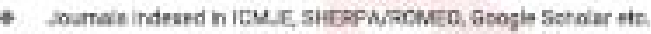

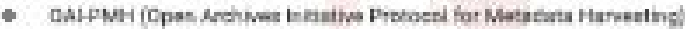

* Deticated Eshoria Batri for nary joutnal

- Acturate and rapid peecrevitw prostss

- hereased etotions of putishad artides through promotisns

\& Redused tmelhe sor artale pitilingtion

Sutont your artioles and exparlavee a now Aurge in patikation terrices

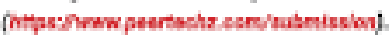

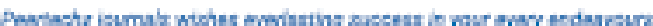

Copyright: (c) 2020 Zelmat SA, et al. This is an open-access article distributed under the terms of the Creative Commons Attribution License, which permits unrestricted use, distribution, and reproduction in any medium, provided the original author and source are credited.

Citation: Zelmat SA, Belhachemie N, Kerbouia DBK, Boucherit E, Mazour F (2020) HELLP syndrome, A real general disease that threatens the maternal morbidity and mortality at the EHU in Oran. J Cardiovasc Med Cardiol 7(2): 094-097. DOI: https://dx.doi.org/10.17352/2455-2976.000120 